\title{
THE ANALYSIS OF FINANCIAL INVOICE AUTOMATION SYSTEM (IAS) BASED ON THE EFFECTIVENESS AND EFFICIENCY IN INVOICE PROCESSING AT THE PROCUREMENT DEPARTMENT: A CASE STUDY OF COMPANY PERINTIS MANDIRI
}

\author{
Choirul Anwar \\ Universitas Negeri Jakarta \\ Jln. Rawamangun Muka, Jakarta 13220 \\ anwar_choirul@yahoo.com
}

\begin{abstract}
Financial invoice processing is an important part of Company Perintis Mandiri's daily business. Today, to catch up the advance of technology development, Company Perintis Mandiri has applied a new financial automatic invoice system called IAS. The scope of this research is the effectiveness and efficiency issues arose from the conversion of financial invoice processing system, from manual to automatic, and the significant differences between them. The research method used is qualitative method, study case approach. To present an objective data analysis, the writer analyzes the internal control of the financial invoice processing systems with COSO theory as the reference, by conducting interviews to the respondents. The writer also analyzes the effectiveness and efficiency between the manual and the automatic system by using a simple numerical measurement. At the end, the result of this research is important to be recognized as an input to develop, maintain, and evaluate the current financial invoice processing system used by Company Perintis Mandiri.
\end{abstract}

Keywords: IAS, Internal Control, COSO

\begin{abstract}
ABSTRAK
Financial invoice processing is an important part of Company Perintis Mandiri's daily business. Today, to catch up the advance of technology development, Company Perintis Mandiri has applied a new financial automatic invoice system called IAS. The scope of this research is the effectiveness and efficiency issues arose from the conversion of financial invoice processing system, from manual to automatic, and the significant differences between them. The research method used is qualitative method, study case approach. To present an objective data analysis, the writer analyzes the internal control of the financial invoice processing systems with COSO theory as the reference, by conducting interviews to the respondents. The writer also analyzes the effectiveness and efficiency between the manual and the automatic system by using a simple numerical measurement. At the end, the result of this research is important to be recognized as an input to develop, maintain, and evaluate the current financial invoice processing system used by Company Perintis Mandiri.
\end{abstract}

Kata kunci: IAS, Internal Control, COSO 


\section{INTRODUCTION}

An invoice is an itemized statement of goods prepared by the vendor listing in the customer's name, items sold, sales price, and terms of sale (Wild, et al., 2007:332). Nowadays, invoice is one of the most important forms of business documentation. It has several important functions, such as: Keeping records effortlessly and accurately by identifying sources of income and keep tracking of expenses, showing professionalism of the company by issuing a professional form of invoice to its customers (Williams, 2010). Before technology has been expanded rapidly, processing an invoice is done with a manual system, starting from the arrival of invoice at the door of the organization until it is posted into the accounting system. Sometimes, a manual invoice process can exceed fifteen steps before the final posting is done. But now is different. Today, a lot of companies use a more advanced technology in processing the third party invoice, by enabling the automation of invoice processing, from arrival to post. As stated in the IOMA's AP Department Benchmarks and Analysis (2010) “The average company with a low level of automation spends $\$ 15.70$ to process an invoice, almost 20 times as much as companies with a high level of automation, where the cost is $\$ 0.74$ ”. This statement shows that invoice automation system is a need of the business world today and Company Perintis Mandiri has been trying to fulfill this need.

Manual invoice processing system is a part of Company Perintis Mandiri's financial invoice processing history. As stated above, to catch up the demand of the business world today, in 2008 Company Perintis Mandiri applied a new automatic invoice system called IAS. Changes make differences, and differences might cause problems. Since financial invoice processing is an important part of Company Perintis Mandiri's daily business, many aspects are needed to consider with the changes. Finding this situation, the writer focuses on The Analysis of Financial Invoice Automation System Based on the Effectiveness and Efficiency in Invoice Processing at Procurement Department in Company Perintis Mandiri. In its daily business, Company Perintis Mandiri through its Finance division handles a lot of types of invoice with various types of payment terms and currencies. To process the invoice until the payment is proceeded, there are several steps to be done accurately and timely manner. Those steps are interrelated together as a system run by the finance division.

Previously, invoices sent to Company Perintis Mandiri were processed with a manual invoice processing system, starting from receiving the invoice, inserting it in the accounting system, conducting the technical approval (for DIV invoice) or matching process (for LIV invoice), and posting it for the next payment process. This manual system was designed as a tool for Finance division to process invoices manually. It did not provide an online workflow, which can be accessed by all users of this system, to check the status (progress) of the invoice processing. This condition required all users of this system to get the original copy of the invoices as their basis to do their job in processing the invoices. But today's condition is different.

During the fourth quarter of 2008, Company Perintis Mandiri has implemented a new system for invoice processing named IAS (Invoice Automation System). IAS project went live on January $8^{\text {th }}$ 2009 and has changed the way Company Perintis Mandiri processed third party invoices. This project is aiming at reducing the need of paper document circulation and also replacing paper document approval with electronic approval. This research is conducted by the writer to analyze the problems arisen from the invoice system conversion, from manual to automation (IAS project). The writer will have a deep discussion about which one, between the manual system and IAS, is more effective and efficient for processing invoices, and finding the significant differences between them in processing an invoice. 


\section{Theoretical Framework and Literature Review}

To make easier in understanding of this research, the theoretical framework of this research can be described as in Figure 1.

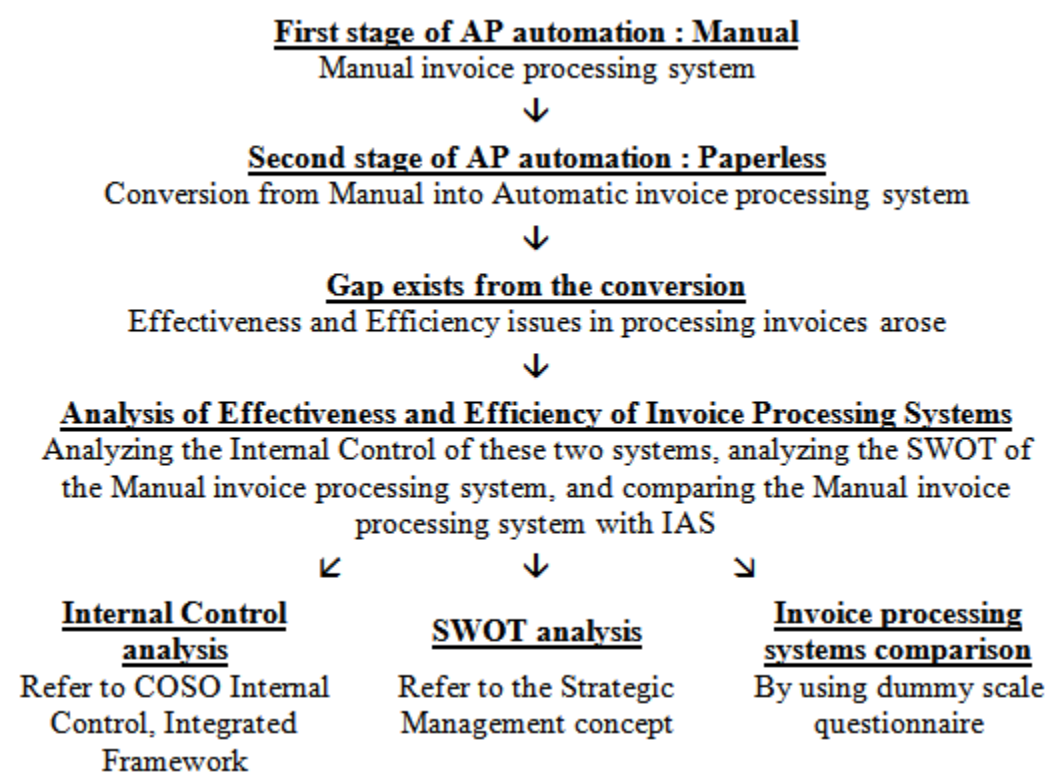

Figure 1 Theoritical Framework

According to Wild, et al., (2007), an invoice is an itemized statement of goods prepared by the vendor listing in the customer's name, items sold, sales price, and terms of sale. An invoice is also a bill sent to the buyer from the supplier. From the vendor's point of view, it is a sales invoice. The buyer (vendee) treats is as a purchase invoice. When receiving a PO, the vendor ships the ordered merchandise to the buyer and includes or mails a copy of the invoice covering the shipment to the buyer. The invoice is sent to the buyer's accounting department where it is placed in the voucher.

From the point of view of a seller, an invoice is a sales invoice. From the point of view of a buyer, an invoice is a purchase invoice. The document indicates the buyer and seller, but the term invoice indicates money is owed or owing. In English, the context of the term invoice is usually used to clarify its meaning, such as "We sent them an invoice" (they owe us money) or "We received an invoice from them" (we owe them money). For a relative small nominal transaction, an invoice is used directly as a document to bill the customer while for the nominal corporate transaction, usually equipped with the invoice or receipt.

Hall (2007, p.231) found that most business entities operate on a credit basis and do not pay for resources until after acquiring them. The time lag between these events splits the procurement process into phases: (1) The physical phase, involving the acquisition of the resource; and (2) the financial phase, involving the disbursement of cash. As a practical matter, these are treated as independent transactions that are processed through separate subsystems. Still referring to Hall (2007), purchases procedures include the task involved in identifying inventory needs, placing the order, receiving the inventory, and recognizing the liability. 
When inventories drop to a predetermined reorder point, a purchase requisition (PR) is prepared and sent to the prepare PO function to initiate the purchase process. While procedures will vary from firm to firm, typically a separate PR will be prepared for each inventory item as the need is recognized. This can result in multiple PRs for a given vendor. These PRs need to be combined into a single PR, which is sent to the vendor. According to Hall (2010), a system is a group of two or more interrelated components or subsystems that serve a common purpose. There are six factors that we have to analyze to gain an understanding about a system itself, they are: multiple components, relatedness, system versus subsystem, purpose, system decomposition, subsystem independency.

In measuring affectivity of system we may refer to COSO determination of internal control which is as stated by Rittenberg, et al. (2008). COSO defines internal control as: a process, effected by an entity's board of directors, management, and other personnel, designed to provide reasonable assurance regarding the achievement of objectives in the following categories: (1) Reliability of financial reporting, (2) compliance with applicable laws and regulations, and (3) effectiveness and efficiency of operations. Furthermore, refer to Rittenberg, et al. (2008), there are five components of the internal control process, they are control environment, risk assessment, control activities, information and communication, and monitoring.

In evaluating internal control, we may use SWOT analysis as stated by Weihrich (1982). Below is the SWOT matrix analysis (Figure 2).

\section{SWOT Matrix}

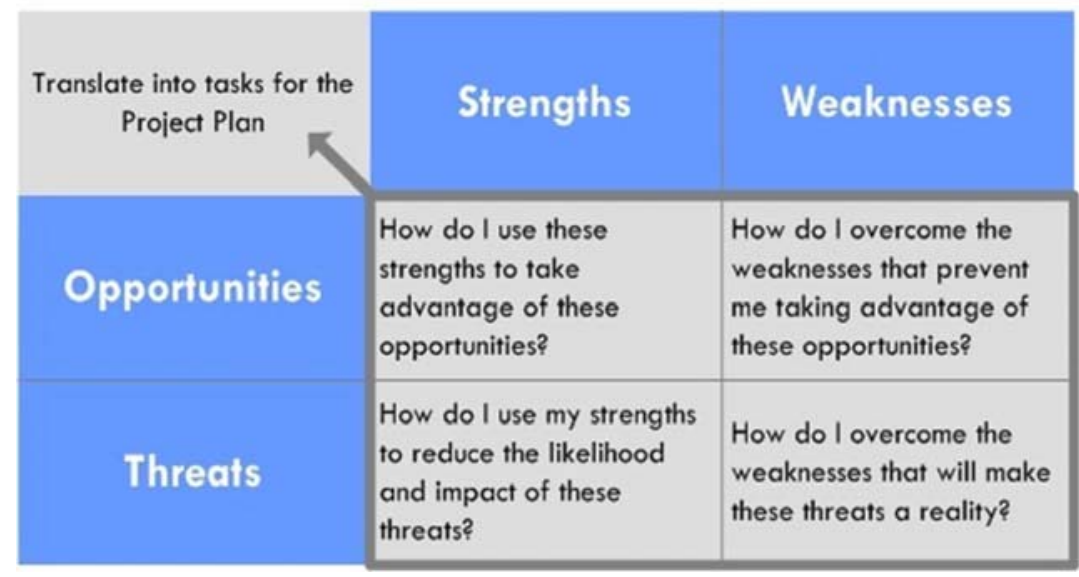

Figure 2 SWOT Matrix

\section{RESEARCH METHODOLOGY}

Based on these four factors such as Research purpose, Research problem, Data shall be gathered, and Audience, the writer decided to choose qualitative as a proper method to be used to analyze the Financial Invoice Automation System (IAS) based on the effectiveness and efficiency in invoice processing at Procurement Department, Company Perintis Mandiri. Refer to the nature of the research problems occurred in this research, the writer decided to use the descriptive analytical design by applying study case approach to analyze the Financial Invoice Automation System (IAS) based on the effectiveness and efficiency in invoice processing at Procurement Department, Company Perintis Mandiri. 
In this study, the writer observed how an invoice is being processed, start from the arrival of the invoice until the invoice is being paid, through IAS, since this is the invoice processing system applied in Company Perintis Mandiri. The data regarding the manual invoice processing system is not gathered with this instrument. Related with the Internal Control, the writer also observe the environment in the Finance division, especially the departments interrelated in the invoice process, based on the components of COSO Internal Control.

In this study, since the writer must analyze the effectiveness and efficiency of the manual and the automation system in processing an invoice, the writer recognized that the most suitable respondents for this condition is the employees who have the responsibilities to process invoices, start from the invoice arrival until the invoice payment, so they will be capable to give important data and share their experience in processing an invoice with those two systems, based on their own responsibilities.

The respondents taken by the writer are as follows:

Table 1 Respondents

\begin{tabular}{clc}
\hline NO & \multicolumn{1}{c}{ PARTICIPANT } & TOTAL \\
\hline 1. & Procurement Department & 1 \\
2. & Clerical Admin & 1 \\
3. & Head of Accounting Department & 1 \\
4. & Coordinator of AP Department & 1 \\
5. & AP Supervisor & 1 \\
6. & Clerk Accounting Admin & 1 \\
7. & Cost Controller & 1 \\
8. & Finance Invoice Approver (User) & 1 \\
\hline & TOTAL OF PARTICIPANT & $\mathbf{8}$ \\
\hline
\end{tabular}

The data analysis conducted in this research is divided into three steps: (1) the writer will analyze the effectiveness and efficiency of the manual invoice processing system and IAS by using questionnaire with dummy scale. (2) The writer analyzes the Internal Control by using the COSO Internal Control, Integrated Framework as the foundation. Then, (3) the writer will analyze the SWOT of the manual invoice processing system using the Strategic Management concept as the fundamental theory.

The reasons of conducting this three-steps analysis are: (1) the effectiveness and efficiency of an operation is one of the objectives to be achieved by COSO Internal Control, Integrated Framework. This matter is also the focus of this research. This is the reason why COSO Internal Control theory is used by the writer as the basis for analyzing the Internal Control of these two systems; (2) the strategic management concept is about why a new strategy has to be implemented. Finding that Company Perintis Mandiri converted its invoice processing system, from manual to automation, made the writer think that there is supposed to be a reason why Company Perintis Mandiri implemented this system as its new strategy in processing invoices; (3) qualitative research is very close to biased and subjective information, resulting from the data analysis. In order to maintain the validity of the information resulted, the writer will use a simple questionnaire with dummy scale incurred, to compare the effectiveness and efficiency of these two systems in processing invoices. 


\section{DISCUSSION}

For getting better view regarding systems in the company Perintis Mandiri writer try to obtain chart of progress invoices that shows the manual invoice system and automation system. The flow of manual invoice processing system in company Perintis Mandiri is shown below (Figure 3).

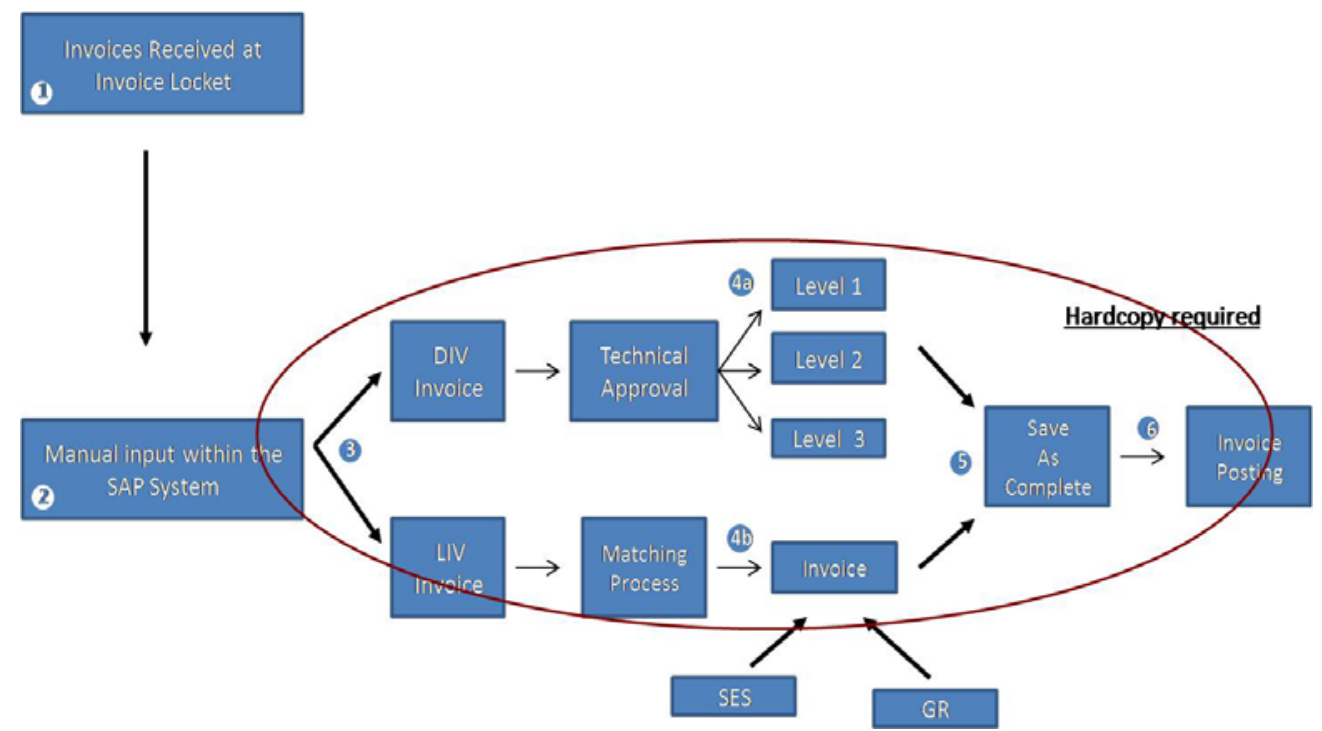

Figure 3 The Flow of Manual Invoice Processing System

The flow of invoice automation system in Company PERINTIS MANDIRI is shown below (Figure 4).

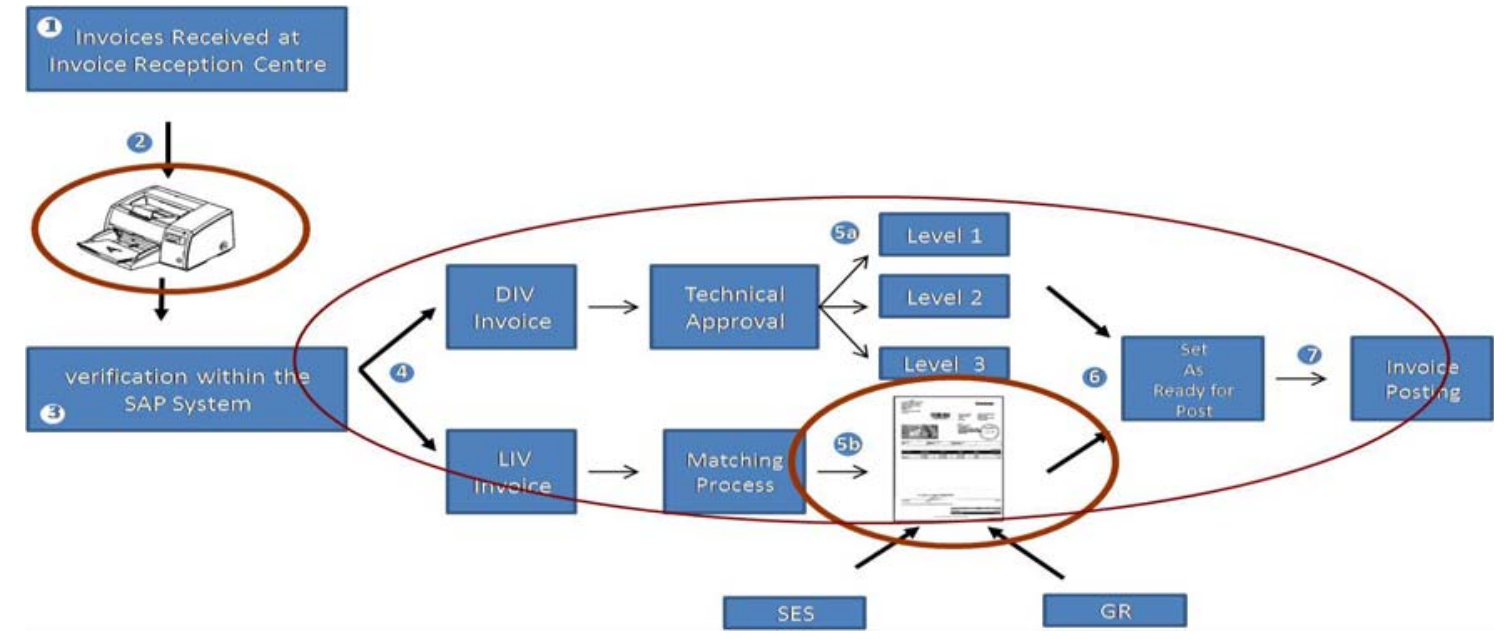

Figure 4 The Flow of Invoice Automation System 
Such mentioned in the methodology data in this research is deployed from result of spreading questionnaire. The result of the computation questionnaire is shown in Table 2.

Table 2 The Result of the Computation Questionnaire

\begin{tabular}{|c|c|c|c|c|c|c|c|c|c|c|c|c|c|c|c|c|c|c|c|}
\hline \multirow{3}{*}{ No. } & & \multirow{3}{*}{ Questions } & \multicolumn{16}{|c|}{ RESPONDENTS } & \multirow{3}{*}{$\begin{array}{c}\text { TOTAL } \\
\text { of } \\
\text { "Yes" } \\
\text { Answer }\end{array}$} \\
\hline & & & \multicolumn{2}{|c|}{$\begin{array}{l}\text { Procurement } \\
\text { Department } \\
\text { (1) }\end{array}$} & \multicolumn{2}{|c|}{$\begin{array}{l}\text { Clerical } \\
\text { Function } \\
\text { (2) }\end{array}$} & \multicolumn{2}{|c|}{ 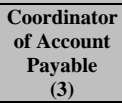 } & \multicolumn{2}{|c|}{$\begin{array}{c}\text { Head } \\
\text { Department } \\
\text { Accounting } \\
(4) \\
\end{array}$} & \multirow{2}{*}{ 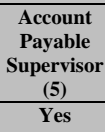 } & \multicolumn{2}{|c|}{$\begin{array}{c}\text { Clerk } \\
\text { Accounting } \\
\text { Admin } \\
(6)\end{array}$} & \multicolumn{3}{|c|}{$\begin{array}{l}\text { Cost } \\
\text { Control } \\
(7)\end{array}$} & \multicolumn{2}{|c|}{$\begin{array}{l}\text { Approver } \\
\text { (8) }\end{array}$} & \\
\hline & & & Yes & No & Yes & No & Yes & No & Yes & No & & No & Yes & No & Yes & No & Yes & No & \\
\hline \multirow[t]{21}{*}{ A. } & & Effectiveness & & & & & & & & & & & & & & & & & \\
\hline & 1. & Target achievement & & & & & & & & & & & & & & & & & \\
\hline & a. & $\begin{array}{l}\text { IAS processes invoices more } \\
\text { precise than MIPS }\end{array}$ & $\checkmark$ & & $\checkmark$ & & $\checkmark$ & & & $\checkmark$ & $\checkmark$ & & $\checkmark$ & & $\checkmark$ & & $\checkmark$ & & 7 \\
\hline & b. & $\begin{array}{l}\text { IAS processes invoices more } \\
\text { accurate than MIPS }\end{array}$ & $\checkmark$ & & $\checkmark$ & & $\checkmark$ & & & $\checkmark$ & $\checkmark$ & & $\checkmark$ & & $\checkmark$ & & $\checkmark$ & & 7 \\
\hline & c. & $\begin{array}{l}\text { My department's target can } \\
\text { be achieved easily by using } \\
\text { IAS than MIPS }\end{array}$ & & $\checkmark$ & $\checkmark$ & & $\checkmark$ & & $\checkmark$ & & $\checkmark$ & & $\checkmark$ & & $\checkmark$ & & $\checkmark$ & & 7 \\
\hline & d. & $\begin{array}{l}\text { Achievement related invoice } \\
\text { processing is increased more } \\
\text { by using IAS than MIPS }\end{array}$ & $\checkmark$ & & $\checkmark$ & & $\checkmark$ & & $\checkmark$ & & $\checkmark$ & & $\checkmark$ & & $\checkmark$ & & $\checkmark$ & & 7 \\
\hline & e. & $\begin{array}{l}\text { Evaluation conducted related } \\
\text { invoice processing is more } \\
\text { decreased by using IAS than } \\
\text { MIPS }\end{array}$ & $\checkmark$ & & & $\checkmark$ & & $\checkmark$ & & $\checkmark$ & $\checkmark$ & & & $\checkmark$ & & $\checkmark$ & $\checkmark$ & & 3 \\
\hline & & & & & & & & & & & & & & & & & & Total & 31 \\
\hline & 2. & Ease of use & & & & & & & & & & & & & & & & & \\
\hline & a. & $\begin{array}{l}\text { IAS has a more detailed } \\
\text { procedure than MIPS (Yes } \rightarrow \\
\text { No.2.b) }\end{array}$ & $\checkmark$ & & $\checkmark$ & & $\checkmark$ & & $\checkmark$ & & $\checkmark$ & & $\checkmark$ & & $\checkmark$ & & & $\checkmark$ & 7 \\
\hline & b. & $\begin{array}{l}\text { This procedure makes the use } \\
\text { of IAS is easier }\end{array}$ & $\checkmark$ & & $\checkmark$ & & $\checkmark$ & & $\checkmark$ & & $\checkmark$ & & $\checkmark$ & & $\checkmark$ & & & $\checkmark$ & 7 \\
\hline & c. & $\begin{array}{l}\text { IAS needs to be understood } \\
\text { deeper than MIPS }\end{array}$ & $\checkmark$ & & $\checkmark$ & & & $\checkmark$ & $\checkmark$ & & & $\checkmark$ & $\checkmark$ & & $\checkmark$ & & $\checkmark$ & & 6 \\
\hline & d. & $\begin{array}{l}\text { Using IAS needs more } \\
\text { adjustments than MIPS }\end{array}$ & & $\checkmark$ & & $\checkmark$ & & $\checkmark$ & $\checkmark$ & & & $\checkmark$ & $\checkmark$ & & & $\checkmark$ & $\checkmark$ & & 3 \\
\hline & e. & $\begin{array}{l}\text { Supervisions and trainings } \\
\text { regarding invoice processing } \\
\text { by using IAS is more } \\
\text { adequate than MIPS }\end{array}$ & & $\checkmark$ & $\checkmark$ & & $\checkmark$ & & $\checkmark$ & & & $\checkmark$ & & $\checkmark$ & & $\checkmark$ & $\checkmark$ & & 4 \\
\hline & & & & & & & & & & & & & & & & & & Total & 27 \\
\hline & 3. & Error Caused & & & & & & & & & & & & & & & & & \\
\hline & & $\begin{array}{l}\text { IAS has a procedure which } \\
\text { regulates actions for doing }\end{array}$ & & & & & & & & & & & & & & & & & \\
\hline & a. & $\begin{array}{l}\text { revision based on mistakes } \\
\text { occurred in the process. (Yes } \\
\rightarrow \text { No.3.b) }\end{array}$ & $\checkmark$ & & $\checkmark$ & & $\checkmark$ & & $\checkmark$ & & & $\checkmark$ & $\checkmark$ & & $\checkmark$ & & & $\checkmark$ & 6 \\
\hline & b. & $\begin{array}{l}\text { The clarity of this procedure } \\
\text { helps more IAS users in } \\
\text { conducting revisions, } \\
\text { compared with MIPS. }\end{array}$ & $\checkmark$ & & $\checkmark$ & & $\checkmark$ & & $\checkmark$ & & & $\checkmark$ & $\checkmark$ & & $\checkmark$ & & & $\checkmark$ & 6 \\
\hline & c. & $\begin{array}{l}\text { The mistakes occurred in } \\
\text { processing invoices are } \\
\text { decreased by using IAS, } \\
\text { compared with MIPS. }\end{array}$ & $\checkmark$ & & $\checkmark$ & & $\checkmark$ & & & $\checkmark$ & & $\checkmark$ & $\checkmark$ & & $\checkmark$ & & $\checkmark$ & & 6 \\
\hline & d. & $\begin{array}{l}\text { Checking and correcting of } \\
\text { mistakes can be done easier } \\
\text { by using IAS than MIPS }\end{array}$ & $\checkmark$ & & $\checkmark$ & & $\checkmark$ & & $\checkmark$ & & & $\checkmark$ & $\checkmark$ & & $\checkmark$ & & $\checkmark$ & & 7 \\
\hline
\end{tabular}


Table 2 The Result of the Computation Questionnaire (continued)

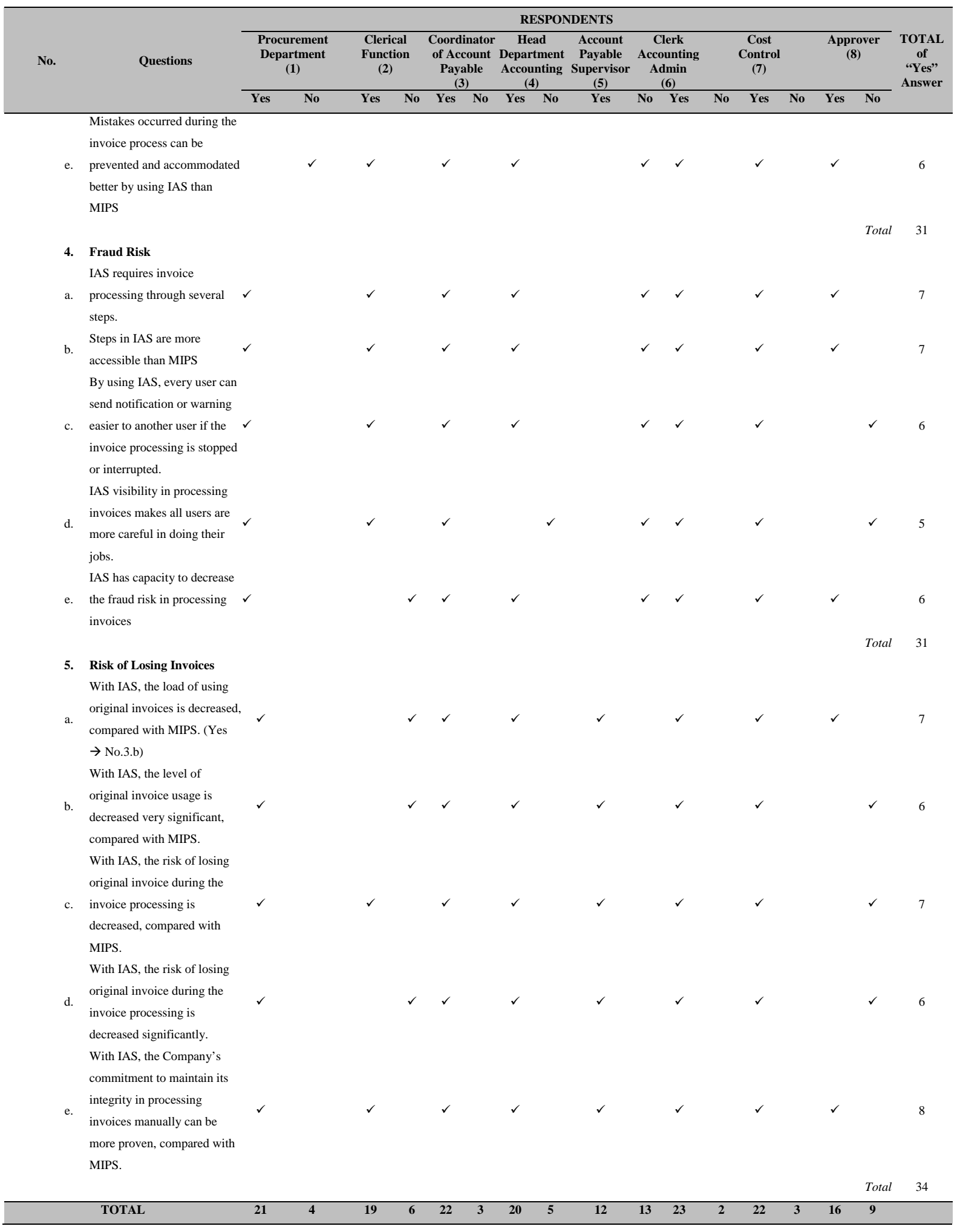


Table 2 The Result of the Computation Questionnaire (continued)

\begin{tabular}{|c|c|c|c|c|c|c|c|c|c|c|c|c|c|c|c|}
\hline \multirow{3}{*}{ No. } & \multirow{3}{*}{ Questions } & \multicolumn{13}{|c|}{ RESPONDENTS } & \multirow{3}{*}{$\begin{array}{c}\text { TOTAL } \\
\text { of } \\
\text { "Yes" } \\
\text { Answer }\end{array}$} \\
\hline & & $\begin{array}{c}\text { Pro } \\
\text { DeI }\end{array}$ & $\begin{array}{l}\text { ment } \\
\text { ment }\end{array}$ & $\begin{array}{l}\text { Cles } \\
\text { Fun }\end{array}$ & & $\begin{array}{r}\text { Coord } \\
\text { of Acc } \\
\text { Paya }\end{array}$ & $\begin{array}{l}\text { inator } \\
\text { ount } \\
\text { ble }\end{array}$ & $\begin{array}{c}\text { Head } \\
\text { Department } \\
\text { Accounting }\end{array}$ & $\begin{array}{c}\text { Account } \\
\text { Payable } \\
\text { Supervisor }\end{array}$ & $\begin{array}{c}\text { Clerk } \\
\text { Accounting } \\
\text { Admin } \\
(6)\end{array}$ & & $\begin{array}{c}\text { Cost } \\
\text { Control } \\
\text { (7) }\end{array}$ & & $\begin{array}{c}\text { Approver } \\
\text { (8) }\end{array}$ & \\
\hline & & Yes & No & Yes & No & Yes & No & Yes No & $\begin{array}{l}\text { Yes } \\
\text { Yes }\end{array}$ & No Yes & No & Yes & No & Yes & \\
\hline
\end{tabular}

B.

Efficiency

1. Time usage

With IAS, the time needed to

a. process invoices becomes

shorter, compared with MIPS

With IAS, the time used for

transferring invoices to

another user for further

process is decreased

significantly, compared with

MIPS.

With IAS, the time used to

remind another user regarding

the invoice processing

progress is decreased

significantly, compared with

MIPS.

With IAS, the time used to

find invoices needed is

decreased significantly,

compared with MIPS.

With IAS, the time used to

file the invoices is decreased

e. significantly, compared with MIPS.

2. Effort

With IAS, the effort needed

a. to process invoices is not as big as when we use MIPS. With IAS, the effort used for transferring invoices to another user for further process is decreased

significantly, compared with MIPS.

With IAS, the effort given to remind another user regarding

the invoice processing

progress is decreased

significantly, compared with

MIPS.

With IAS, the effort given to

find invoices needed is

d. decreased significantly,

compared with MIPS.

With IAS, the effort given to

file the invoices is decreased

e. significantly, compared with MIPS. 
Table 2 The Result of the Computation Questionnaire (continued)

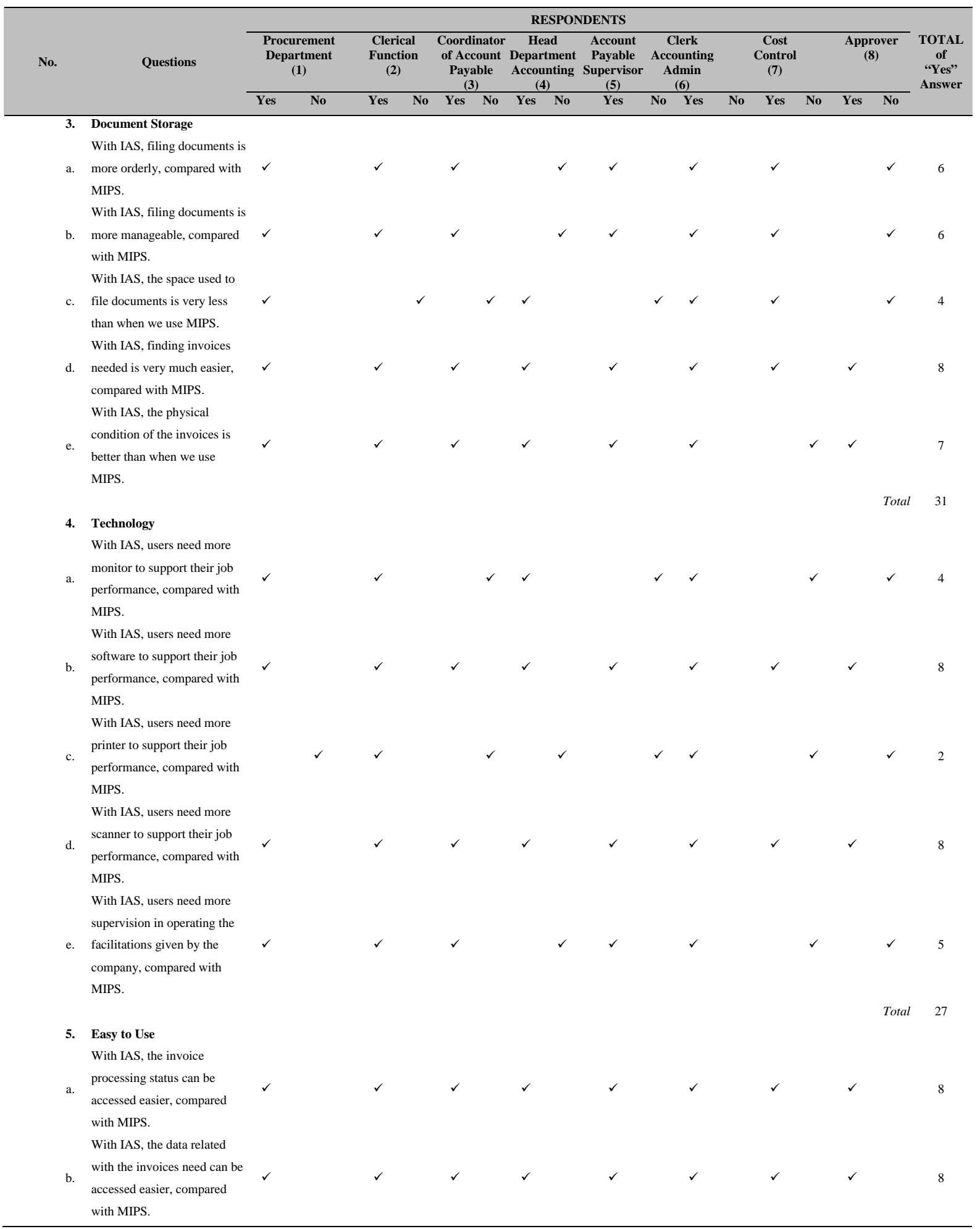


Table 2 The Result of the Computation Questionnaire (continued)

\begin{tabular}{|c|c|c|c|c|c|c|c|c|c|c|c|c|c|c|c|c|c|c|}
\hline \multirow[t]{3}{*}{ No. } & \multirow[t]{3}{*}{ Questions } & \multicolumn{16}{|c|}{ RESPONDENTS } & \multirow{3}{*}{$\begin{array}{c}\text { TOTAL } \\
\text { of } \\
\text { "Yes" } \\
\text { Answer }\end{array}$} \\
\hline & & \multicolumn{2}{|c|}{$\begin{array}{l}\text { Procurement } \\
\text { Department } \\
\text { (1) }\end{array}$} & \multicolumn{2}{|c|}{$\begin{array}{l}\text { Clerical } \\
\text { Function } \\
\text { (2) }\end{array}$} & \multicolumn{2}{|c|}{$\begin{array}{c}\text { Coordinator } \\
\text { of Account } \\
\text { Payable } \\
\text { (3) }\end{array}$} & \multicolumn{2}{|c|}{$\begin{array}{c}\text { Head } \\
\text { Department } \\
\text { Accounting } \\
\text { (4) }\end{array}$} & \multirow[t]{2}{*}{$\begin{array}{c}\begin{array}{c}\text { Account } \\
\text { Payable } \\
\text { Supervisor } \\
\text { (5) }\end{array} \\
\text { Yes }\end{array}$} & \multicolumn{2}{|c|}{$\begin{array}{c}\text { Clerk } \\
\text { Accounting } \\
\text { Admin } \\
(6)\end{array}$} & \multicolumn{3}{|c|}{$\begin{array}{l}\text { Cost } \\
\text { Control } \\
\text { (7) }\end{array}$} & \multicolumn{2}{|c|}{$\begin{array}{c}\text { Approver } \\
\text { (8) }\end{array}$} & \\
\hline & & Yes & No & Yes & No & Yes & No & Yes & No & & No & Yes & No & Yes & No & Yes & No & \\
\hline c. & $\begin{array}{l}\text { With IAS, manual invoice } \\
\text { inputting process is } \\
\text { decreased, compared with } \\
\text { MIPS. (Yes } \rightarrow \text { No. 5.d.) }\end{array}$ & & $\checkmark$ & $\checkmark$ & & $\checkmark$ & & $\checkmark$ & & $\checkmark$ & & $\checkmark$ & & $\checkmark$ & & $\checkmark$ & & 7 \\
\hline d. & $\begin{array}{l}\text { With IAS, the load of manual } \\
\text { invoice inputting process is } \\
\text { decreased significantly. } \\
\text { With IAS, users can accessed }\end{array}$ & $\checkmark$ & & $\checkmark$ & & $\checkmark$ & & $\checkmark$ & & $\checkmark$ & & $\checkmark$ & & $\checkmark$ & & $\checkmark$ & & 8 \\
\hline e. & $\begin{array}{l}\text { invoices needed faster, } \\
\text { compared with MIPS. }\end{array}$ & $\checkmark$ & & & $\checkmark$ & $\checkmark$ & & $\checkmark$ & & $\checkmark$ & & $\checkmark$ & & $\checkmark$ & & $\checkmark$ & & 7 \\
\hline & & & & & & & & & & & & & & & & & Total & 38 \\
\hline & TOTAL & 19 & 6 & 21 & 4 & 22 & 3 & 19 & 6 & 22 & 3 & 24 & 1 & 20 & 5 & 15 & 10 & \\
\hline
\end{tabular}

Scoring :

Yes $=1 ;$ No $=1$

Based on the questionnaire computation, the analysis will be divided into effectiveness and efficiency.

\section{Effectiveness}

For effectiveness, there is no established standard to measure the level of effectiveness. However, the writer should measure the data analysis based on an established standard. Therefore, the writer held a discussion with the writer and the management, then Company PERINTIS MANDIRI decided that the minimum percentage required to represent the effectiveness of its financial invoice processing system is $80 \%$ from Yes answer. So in this case, the $80 \%$ represents 20 answer, proven by the computation of $80 \% \times 25=20$. The result shown that as in Table 3 .

Table 3 The result of Effectiveness

\begin{tabular}{|c|c|c|c|c|c|c|c|c|}
\hline & $\begin{array}{c}\text { Respondent } \\
1 \\
\end{array}$ & $\begin{array}{c}\text { Respondent } \\
2 \\
\end{array}$ & $\begin{array}{c}\text { Respondent } \\
3 \\
\end{array}$ & $\begin{array}{c}\text { Respondent } \\
4 \\
\end{array}$ & $\begin{array}{c}\text { Respondent } \\
5 \\
\end{array}$ & $\begin{array}{c}\text { Respondent } \\
6 \\
\end{array}$ & $\begin{array}{c}\text { Respondent } \\
7 \\
\end{array}$ & $\begin{array}{c}\text { Respondent } \\
8 \\
\end{array}$ \\
\hline $\begin{array}{c}\text { Ratio } \\
\text { (Yes : No) }\end{array}$ & $21: 4$ & $19: 6$ & $22: 3$ & $20: 5$ & $12: 13$ & $23: 2$ & $22: 3$ & $16: 9$ \\
\hline
\end{tabular}

Based on the standard agreed, that writer can take analysis that from eight respondents related with the invoice processing system internally, there are five respondents who agreed that IAS is more effective than Manual Invoice Processing System.

\section{Efficiency}

For effectiveness, included in the discussion mentioned above, Company Perintis Mandiri decided that the minimum percentage required to represent the efficiency of its financial invoice processing system is also $80 \%$ from Yes answer. So in this case, the $80 \%$ represents 20 answer, proven by the computation of $80 \%$ x $25=20$. The result shown that as in Table 4 . 
Table 4 The result of efficiency

\begin{tabular}{ccccccccc}
\hline & $\begin{array}{c}\text { Respondent } \\
\mathbf{1}\end{array}$ & $\begin{array}{c}\text { Respondent } \\
\mathbf{2}\end{array}$ & $\begin{array}{c}\text { Respondent } \\
\mathbf{3}\end{array}$ & $\begin{array}{c}\text { Respondent } \\
\mathbf{4}\end{array}$ & $\begin{array}{c}\text { Respondent } \\
\mathbf{5}\end{array}$ & $\begin{array}{c}\text { Respondent } \\
\mathbf{6}\end{array}$ & $\begin{array}{c}\text { Respondent } \\
\mathbf{7}\end{array}$ & $\begin{array}{c}\text { Respondent } \\
\mathbf{8}\end{array}$ \\
\hline $\begin{array}{c}\text { Ratio } \\
\text { (Yes }\end{array}$ & $19: 6$ & $21: 4$ & $22: 3$ & $19: 6$ & $22: 3$ & $24: 1$ & $20: 5$ \\
$\mathbf{: N o})$ & & & & & & & & \\
\hline
\end{tabular}

Based on the standard agreed, that writer can take analysis that from eight respondents related with the invoice processing system internally, there are also different five respondents who agreed that IAS is more efficient than Manual Invoice Processing System.

There has to be a reason why IAS is implemented as a new financial invoice processing system in the Finance department. There has to be a bottom line why IAS was implemented as a new financial invoice processing strategy. In this section, the writer will try to make a SWOT analysis of the Manual Invoice Processing System.

Table 5 SWOT Analysis of the Manual Invoice Processing System

\begin{tabular}{|c|c|c|}
\hline EXTERNAL & $\begin{array}{l}\text { STRENGTHS } \\
\text { - The assurance gotten because the } \\
\text { data inputted is based on strong } \\
\text { reliance on the original copy of } \\
\text { financial invoices during the } \\
\text { financial invoice processing } \\
\text { - It does not require an advanced } \\
\text { software or a big scanner to } \\
\text { process financial invoices }\end{array}$ & $\begin{array}{l}\text { WEAKNESSES } \\
\text { - } \quad \text { According to MAP (2009, p. 12, cited in } \\
\text { www.AccountsPayable360.com) : } \\
\text { - } \quad \text { High cost of processing invoice } \\
\text { - } \quad \text { Weak internal control } \\
\text { - } \quad \text { High human error } \\
\text { - } \quad \text { Capture less discounts } \\
\text { High usage of time and effort for finding } \\
\text { financial invoices needed, transferring financial } \\
\text { invoices need to be processed, and reminding for } \\
\text { the next user of the system to continue the } \\
\text { financial invoices processing. } \\
\text { Less visibility in accessing the status of the } \\
\text { financial invoice processing }\end{array}$ \\
\hline $\begin{array}{l}\text { OPPORTUNITIES } \\
\text { Most of the third parties (vendor) } \\
\text { send their invoices in form of } \\
\text { paper. }\end{array}$ & $\begin{array}{l}\text { The financial invoice processing is } \\
\text { basically can be done manually. }\end{array}$ & $\begin{array}{l}\text { Trying to process financial invoices accurately and } \\
\text { timely manner based on the procedures. }\end{array}$ \\
\hline $\begin{array}{l}\text { THREATS } \\
\text { High risk of losing original copy of } \\
\text { financial invoices during the } \\
\text { financial invoice process. }\end{array}$ & $\begin{array}{l}\text { Sending the financial invoices to the } \\
\text { next user with a receipt, which needs to } \\
\text { be signed, as approve that he/she has } \\
\text { received the invoices. }\end{array}$ & $\begin{array}{l}\text { By implementing a new strategy that can decrease the } \\
\text { high cost of processing financial invoices, overcome a } \\
\text { strong internal control, decrease human error, capture } \\
\text { more discount, less usage of time and effort to find } \\
\text { financial invoices needed, transferring financial } \\
\text { invoices need to be processed, and reminding for the } \\
\text { next user of the system to continue the financial } \\
\text { invoices processing, high visibility of invoice } \\
\text { processing status, and decrease the risk of losing the } \\
\text { original copy of financial invoices during the process. }\end{array}$ \\
\hline
\end{tabular}




\section{CONCLUSION}

\section{Conclusion}

Based on the data analysis in, the writer came up with some conclusions. IAS is more effective than manual invoice processing system, which means from (1) the Internal Control side, Yes, IAS is more effective than the Manual Invoice Processing system. Because, IAS provides a better Internal Control by increasing the visibility and transparency of invoice processing. Nonetheless, there are still several weaknesses insight, such as the segregation of duties is not very tight (some departments sometimes still work in team-work). But, applying IAS makes each employee related with the financial invoice processing has more limitation segregated automatically in the system; (2) from the numerical comparison, Yes, it is more effective, because most of the respondents' answers show that IAS is more effective for them in doing their job.

IAS is more efficient than manual invoice processing system, which means (1) from the Internal Control side, Yes, IAS is more efficient than the Manual Invoice Processing system. Related with the effectiveness explanation, applying IAS makes each employee related with the financial invoice processing has more limitation segregated automatically in the system, so it decreases the time used and effort given to do the same job; (2) from the numerical comparison, yes, it is more efficient, because most of the respondents' answers show that IAS is more effective for them in doing their job.

The Significant Differences between IAS and Manual Invoice Processing System are: (1) in terms of effectiveness, the most significant difference between IAS and Manual Invoice Processing System is the "Risk of Losing Invoices", shown by the highest total of Yes answer, which is 34 answers; (2) in terms of efficiency, the most significant difference between IAS and Manual Invoice Processing System is the "Easy to Use", shown by the highest total of Yes answer, which is 38 answers.

\section{Recommendation}

Based on the conclusion taken above, the writer recommends Company PERINTIS MANDIRI to keep applying, developing, and evaluating IAS as the invoice processing system used in Finance division, Company PERINTIS MANDIRI, by: (1) keep using IAS to help the employees in the Finance division to process incoming invoices; (2) discussing any difficulties occured during the process with the responsible hierarchy (coordinator or head of the department); (3) conducting an evaluation meeting (done by each department included in the invoice processing) about the achievement of its goals related with the invoice processing with IAS and applying the solution; (4) buliding a good cooperation with the IT department (method department in Company Perintis Mandiri). Since IAS is built from computerized system and software, which is not the major competency had by the employees in Finance Division, it is important to build a good cooperation with the IT department. Because, if there are difficulties related with the system or other components in the IT field, the Finance department can communicate it easier to the IT department and find the best solution which can accomodates the needs of both departments. 


\section{REFERENCES}

Hall, J. A. (2007). Accounting Information Systems (5th ed.). USA: Thomson South-Western.

IOMA (2010). AP Department Benchmarks and Analysis 2010 report. Greenwich, Connecticut: Institute of Finance and Management.

Rittenberg, L.E., Schwieger, B. J., \& Johnstone, K. M. (2008). AUDITING, A Business Risk Approach (6th ed.). USA: Thomson South-Western.

Weihrich, H. (1982). The TOWS matrix - a tool for situational analysis, Journal of Long Range Planning, Vol. 15, No. 2.

Wild, J. J., Larson, K. D., \& Chiappetta, B. (2007). Fundamental Accounting Principle (18th ed.). USA: McGraw-Hill. 